\title{
A study of the Unna Boot compared with the elastic bandage in venous ulcers: a randomized clinical trial ${ }^{1}$
}

\author{
Alcione Matos de Abreu² \\ Beatriz Guitton Renaud Baptista de Oliveira ${ }^{3}$
}

Objective: to analyze the process of tissue repair in patients with venous ulcers using inelastic compression therapy (the Unna Boot), in comparison with the use of the elastic bandage. Method: a controlled randomized clinical trial in which the patients $(n=18)$ were allocated to two groups, those who used the Unna Boot (group B) and those who used the elastic bandage (group A). The study's follow-up period was 13 weeks. Results: a significant reduction took place, at the level of $5 \%$, in the area, in square centimeters, of the ulcers of group $B(p<0.0001)$ throughout the treatment, and there was a tendency of group A for reduction in the area of the ulcer, in centimeters squared $(p=0.06)$, only after the fifth week. Conclusion: the treatment with the Unna Boot presented better results in venous ulcers with areas over $10 \mathrm{~cm}^{2}$, and the elastic bandage with Petrolatum $\AA$ gauze in venous ulcers below $10 \mathrm{~cm}^{2}$. Brazilian Clinical Trials Register: Trial (req: 195) and WHO UTN U1111-1122-5489.

Descriptors: Bandages; Varicose Ulcer; Nursing.

\footnotetext{
${ }^{1}$ Paper extracted from master's thesis "Usa of Unna Boot in Comparison to Elastic Bandage in Patients with Venous Ulcers: Clinical Study", presented to Universidade Federal Fluminense, Niterói, RJ, Brazil.

2 Doctoral student, Escola de Enfermagem Aurora de Afonso Costa, Universidade Federal Fluminense, Niterói, RJ, Brazil. Scholarship holder from Coordenação de Aperfeiçoamento de Pessoal de Níve Superior (CAPES), Brazil.

${ }^{3}$ PhD, Full Professor, Escola de Enfermagem Aurora de Afonso Costa, Universidade Federal Fluminense, Niterói, RJ, Brazil.
}

Corresponding Author:

Alcione Matos de Abreu

Universidade Federal Fluminense

Rua Doutor Celestino, 74

Centro

CEP: 24020-091, Niterói, RJ, Brasil

E-mail: alci_abreu@yahoo.com.br
Copyright () 2015 Revista Latino-Americana de Enfermagem This is an Open Access article distributed under the terms of the Creative Commons Attribution Non-Commercial License (CC BY-NC).

This license lets others distribute, remix, tweak, and build upon your work non-commercially, and although their new works must also acknowledge you and be non-commercial, they don't have to license their derivative works on the same terms. 


\section{Introduction}

The principal course of ulcers of venous etiology is venous hypertension and the consequent capillary hypertension(1). The treatment of this type of ulcer must be directed towards the attempt to revert the venous hypertension at the level of the superficial veins of the lower members ${ }^{(1)}$. As a result, treatment with compression therapy is indicated for patients with chronic venous insufficiency, as this acts on the macrocirculation, increasing the venous return and the tissue pressure, favoring the reabsorption of the edema and causing the fluids located in the interstitial spaces to return to within the vascular and lymphatic systems ${ }^{(1)}$.

The therapeutic approach of patients with venous ulcers must be based, in the majority of cases, in compression therapy ${ }^{(2-3)}$ and in the topical treatment of the ulcer ${ }^{(2-3)}$ while, in more serious cases, treatment with systemic medications and surgery may be added(3). The inadequate control of venous hypertension is directly proportional to the increase in the rates of recurrence of ulcers with venous etiology(1).

There is, at the present time, a large number of different types of compression therapies on the market for the treatment of wounds, however, it is not yet clear if all of these are genuinely effective, or which of these therapies is the best indication for the treatment of chronic venous ulcers ${ }^{(1,3-5)}$.

The Unna Boot is a form of inelastic compression therapy, acting in such a way as to increase the compression and promote venous drainage and support, thus benefiting the healing of the ulcer ${ }^{(2-6)}$. These inelastic bandages create high pressure with the muscular contraction (during walking) and little pressure at rest. For this reason, it is essential for the nurse to observe whether the patient continues to undertake her daily activities, such as work-related, or taking short walks, when she is using the Unna Boot, in order to implement the action of the product(1,3-6).

Another type of compression therapy existing on the market is the elastic bandages, made with elastic fibers which provide compression and remain in place in movement and at rest. During walking, the muscles of the calf contract and the bandage expands, dissipating the strength exercised by the contraction of this musculature and promoting the venous return to the heart ${ }^{(3-6)}$. These bandages are classified as of high compression type III, as they exercise adequate pressure on an ankle of 18 through to $25 \mathrm{~cm}$ in circumference ${ }^{(4)}$. They are washable and can be reusable(4).
This study's objective was to analyze the process of tissue repair of patients with venous ulcers using inelastic compression therapy (the Unna Boot), in comparison with the use of the elastic bandage.

\section{Methods}

This is a controlled and randomized clinical trial. The study was undertaken in an outpatient center specialized in treating wounds at a teaching hospital in the State of Rio de Janeiro, Brazil.

The sample was consecutive, and was initially composed of 19 (nineteen) patients admitted to the outpatient center between $7^{\text {th }}$ June and $20^{\text {th }}$ September 2011, and who met the eligibility criteria. In the randomization, 10 (ten) patients were allocated to group A (elastic bandage) and 9 (nine) to group B (Unna Boot). One patient from group A was excluded due to not attending the consultations. The randomization was implemented by the Research Unit's statistician, using a table of random numbers, generated by the Biostat 5.0 software and applied as the patients were included in the study. The follow-up period was thirteen weeks.

The inclusion criteria were: walking patients, over 18 years old; with a medical diagnosis of Chronic Venous Insufficiency (CVI), not diabetic; presenting palpable dorsalis pedis and posterior tibial pulses, with an anklebrachial index $(A B I)$ of $>0.9$, a venous ulcer with a minimum size of $6.0 \mathrm{~cm}^{2}$ and a maximum of $9.0 \mathrm{~cm}^{2}$. The following were excluded: pregnant women; patients with signs of allergy, cyanosis, with venous ulcers which were infected and/or with necrotic tissue, and who discontinued use of the therapies.

Data collection was undertaken between June and December 2011, and was divided in two stages: in the first stage, there was the initial approach and signing of the Terms of Free and Informed Consent (TFIC) and authorization for making photographic records of the lesion. In the second stage, the weekly consultations were held with a medical history, clinical evaluation of the patient and of the wound, changing of dressings, planimetrics and digital photographs.

The changing of the dressing and the evaluation of the wound were undertaken weekly in the outpatient center by the same trained researcher. They were undertaken daily at home by the patient subsequent to receiving guidance, training and explanatory leaflets. Both groups changed the secondary dressing with the objective of preventing odor and the accumulation of exudate. In accordance with the prescription and the 
maker's recommendations, the elastic bandage group (group A) removed the bandage at night and put it back on in the morning. For the beginning of the reapplication of the bandage, the bandage was rolled from the center of the sole of the foot, with the lower end of the bandage being placed at the base of the toes, rolling it around the heel and rising upwards until $2 \mathrm{~cm}$ below the knee. The force applied in the bandage was controlled by the change in format of the design, from rectangular to square.

In order to apply the dressing at home, the patients were supplied weekly with a "dressing kit", containing the following materials: 6 crêpe bandages, 6 packets with 10 units of sterile gauze and one container of adhesive tape. For Group A, in addition to the dressing kit, two elastic graduated compression bandages were supplied.

The changing of the dressing in the outpatient center was based on cleaning with $0.9 \%$ saline solution, at room temperature, in the form of irrigation using a $40 \times 12 \mathrm{~mm}$ needle. The cleaning of the perilesional area was undertaken with neutral soap and $0.9 \%$ saline solution. Only the margins were dried in order to avoid maceration of the perilesional tissue. The wound bed was kept humid, in order to promote the process of tissue repair.

In group $A$, Petrolatum ${ }^{\circledR}$ gauze was used on the wound bed, for a period of time of seven days, in order to maintain the humidity; in group $B$, the Unna Boot was applied directly to the wound.

The primary outcome was the reduction of the area, in $\mathrm{cm}^{2}$, of the venous ulcers over the 13 (thirteen) weeks of treatment in groups A and B. The data were evaluated using the technique of planimetrics and photography in the $1^{\text {st }}, 5^{\text {th }}, 9^{\text {th }}$ and $13^{\text {th }}$ weeks of treatment in both groups. The calculation of the percentage of final reduction of the areas of the ulcers was calculated using the following formula:

Percentage of reduction of the area of the venous ulcer = $\frac{[(\text { Initial area-Final area }) \times 100]}{\text { Initial area }}$

The secondary outcomes detected were the increase in granulation tissue, reduction of the quantity of exudate, and reduction in edema and pain. These outcomes were evaluated through instruments and protocols of the wound outpatient center. The quantity of granulation tissue was assessed as: absent, from 1 to $25 \%$, from 26 to $50 \%$, from 51 to $75 \%$, and from 76 to
$100 \%$ of the total area of the lesion. In relation to the exudate, the quantity was assessed as: absent, when the wound bed was found to be dry; little, when the wound bed was at high humidity and involved draining of less than $25 \%$ of the dressing; moderate, when the wound bed was saturated and the draining involved from 25 to $75 \%$; and big, when the wound bed was bathed in fluid and draining involved more than $75 \%$ of the dressing ${ }^{(7)}$. The pain was assessed using the Numeric Rating Scale, graduated from 0 to $10^{(8)}$.

The demographic variables were: age and sex, and the health variables were: underlying diseases, and the location of the lesion, eczema, Body Mass Index (BMI) and Ankle-Brachial Index (ABI).

The comparison of the sociodemographic and clinical variables, and those related to the lesion, between the two groups ( $A$ and $B$ ) were analyzed using the Student t-test (independent samples) or Mann-Whitney test, for numerical data, and using the Fisher exact test, for categorical data.

The variation of the area of the ulcer obtained at the four different points ( $1^{\text {st }}, 5^{\text {th }}, 9^{\text {th }}$ and $13^{\text {th }}$ consultations) in each group was evaluated using the Friedman ANOVA and the corresponding Nemenyi multiple comparison test (non-parametric), which identifies which points differ significantly between each other; the criteria for determining significance adopted was the level of $5 \%$. The results were analyzed through descriptive and inferential statistics, using the SAS software, version 6.11 .

This study was approved by the Research Ethics Committee of the Faculty of Medicine, under Protocol N. 327/10 and CAAE: 0252.0.258.000-10; the patients were offered the continuation of the treatment after the 13 (thirteen) weeks of data collection.

\section{Results}

A total of 18 patients participated in the study, 9 in group A (elastic bandage) and 9 in group B (Unna Boot), and were monitored for 13 weeks, totaling 252 nursing consultations.

Table 1 provides the descriptive, demographic and clinical analysis respectively, by treatment group ( $A$ and $B$ ).

One can observe, in Table 2, that there is a significant reduction in the size of the ulcers over the course of the treatment, $\left(1^{\text {st }}, 5^{\text {th }}, 9^{\text {th }}, 13^{\text {th }}\right)$ only in group $B(p<0.0001)$, with a significant reduction in the size of the area of the ulcer from the $1^{\text {st }}$ to the $5^{\text {th }}$ 
consultation, the $9^{\text {th }}$ to the $13^{\text {th }}$, and from the $5^{\text {th }}$ to the $13^{\text {th }}$. In group $A$, there was a tendency for reduction of the area of the ulcer $(p=0.06)$, only after the $5^{\text {th }}$ consultation.

Table 1 - Distribution of the demographic and clinical variables, according to each treatment group, found in the $1^{\text {st }}$ consultation. Niterói, RJ, Brazil, 2012

\begin{tabular}{|c|c|c|c|c|c|c|}
\hline \multirow{2}{*}{ Variable } & \multirow[t]{2}{*}{ Category } & \multicolumn{2}{|c|}{ Group A } & \multicolumn{2}{|c|}{ Group B } & \multirow{2}{*}{$\begin{array}{c}p \\
\text { value* }^{*}\end{array}$} \\
\hline & & $\mathbf{N}$ & $\%$ & $\mathbf{N}$ & $\%$ & \\
\hline Age & (years) & \multicolumn{2}{|c|}{$56.6 \pm 18.0$} & \multicolumn{2}{|c|}{$56.3 \pm 14.1$} & 0.97 \\
\hline \multirow[t]{2}{*}{ Sex } & Male & 6 & 66.7 & 5 & 55.6 & 0.50 \\
\hline & Female & 3 & 33.3 & 4 & 44.4 & \\
\hline $\mathrm{SAH}+\mathrm{CVI}^{\dagger}$ & Yes & 5 & 55.6 & 6 & 66.7 & 0.50 \\
\hline $\begin{array}{l}\text { Time of the } \\
\text { lesion }^{\dagger}\end{array}$ & Months & 9 & $(4-120)$ & 9 & $(6-120)$ & 0.076 \\
\hline $\begin{array}{l}\text { Location of } \\
\text { the lesion }\end{array}$ & Malleolus & 7 & 77.8 & 7 & 77.8 & 0.77 \\
\hline Eczema & Present & 9 & 100 & 9 & 100 & $\mathrm{NSA}^{\S}$ \\
\hline BMIII & $\left(\mathrm{kg} / \mathrm{m}^{2}\right)$ & \multicolumn{2}{|c|}{$24.4 \pm 4.5$} & & $29.1 \pm .6$ & 0.074 \\
\hline$\left.A B\right|^{\pi}$ & & \multicolumn{2}{|c|}{$1.10 \pm 0.13$} & & $1.19 \pm 0.17$ & 0.24 \\
\hline
\end{tabular}

${ }^{*}$ p value Fisher's exact test

+Systemic Arterial Hypertension + Chronic Venous Insufficiency

¥Time of evolution of the wound was expressed as median (minimummaximum)

$\S$ Absolute absence or presence of cases in the variable

||Body Mass Index

१Ankle-Brachial Index

Two patients presented total healing of their ulcers, the patient from group $A$ in the $9^{\text {th }}$ week, and the patient from group $B$ in the $13^{\text {th }}$ week. It is highlighted that all the ulcers monitored by the study had suffered relapses in a period of time below five years.

Based on the calculation of the percentage of the final reduction of the area of the venous ulcers, one can state that group B $(69.41 \%)$ presented a higher percentage of value of reduction of the ulcers' area, in comparison with group A (42.32\%).

At the end of the thirteen weeks of monitoring, the two groups presented granulation tissue in the wound beds. In relation to the quantity of exudate, group $B$ presented a greater reduction in the production of exudate in comparison with group $A$.

Intense edema graded at $+3 /+4$, which was initially evaluated in $88.9 \%$ of the patients, progressed at the end of the study to mild edema $(+1 /+4)$ in the same.

The majority of the patients $(80 \%)$ report having stopped using pain killers for undertaking activities of daily living, classifying the pain, at the end of the study, on a numerical scale with values from 0 to 4 .

In relation to the inconvenience of the use of compression therapy, the groups reported improvement in the discomfort and the pain after the first five weeks of treatment.

Ochre dermatitis was found in all the lower limbs affected by the venous ulcers. In the elastic bandage group, the appearance of crusts was observed on the margins of all the ulcers; in the Unna Boot group, the ulcers presented periwound maceration.

Table 2 - Area of the ulcer (in $\mathrm{cm}^{2}$ ), over the 13 weeks of monitoring, according to treatment group. Niterói, RJ, Brazil, 2012

\begin{tabular}{|c|c|c|c|c|c|}
\hline Group & Evaluation & Median & Minimum-Maximum & p value* & $\begin{array}{l}\text { Significant } \\
\text { differences }^{\dagger}\end{array}$ \\
\hline \multirow{4}{*}{$\begin{array}{c}A \\
(n=9)\end{array}$} & $1^{\text {st }}$ consult & 15.0 & $6-52.5$ & 0.060 & \\
\hline & $5^{\text {th }}$ consult & 7.0 & $3.5-59.5$ & & \\
\hline & $9^{\text {th }}$ consult & 9.0 & $0-19.5$ & & \\
\hline & $13^{\text {th }}$ consult & 8.0 & $0-61.5$ & & \\
\hline \multirow{4}{*}{$\begin{array}{c}B \\
(n=9)\end{array}$} & $1^{\text {st }}$ consult & 28.0 & $13.5-82$ & $<0.0001$ & $1^{\text {st }} \neq 5^{\text {th }}$ \\
\hline & $5^{\text {th }}$ consult & 19.0 & $8.5-32$ & & $1^{\text {st }} \neq 9^{\text {th }}$ \\
\hline & $9^{\text {th }}$ consult & 11.5 & $5-42$ & & $1^{\text {st }} \neq 13^{\text {th }}$ \\
\hline & $13^{\text {th }}$ consult & 9.0 & $0-28$ & & $5^{\text {th }} \neq 13^{\text {th }}$ \\
\hline
\end{tabular}

*Friedman ANOVA

+Nemenyi multiple comparison test, at the level of $5 \%$

In relation to the hydration of the perilesional skin, at the end of the thirteen weeks, it was observed that the areas adjacent to the ulcers were more hydrated in all the patients in comparison with the first assessment. It is important to note that prior to the beginning of data collection, all of the patients in the study had ulcers with relapses within a five year period.
There was no significant statistical difference, at the level of $5 \%$, in any of the variables belonging to the two treatment groups, with the exception of the clinical variable of edema. Thus, one can state that the two comparative groups were made up of a homogenous sample. 
Table 3 - Analysis of the variables of the ulcers in the first consultation, by treatment group. Niterói, RJ, Brazil, 2012

\begin{tabular}{|c|c|c|c|c|c|c|}
\hline \multirow{2}{*}{ Variable } & \multirow{2}{*}{ Category } & \multicolumn{2}{|c|}{ Group A } & \multicolumn{2}{|c|}{ Group B } & \multirow{2}{*}{ p value* } \\
\hline & & $\mathbf{n}$ & $\%$ & $\mathbf{n}$ & $\%$ & \\
\hline \multirow{4}{*}{$\begin{array}{l}\text { Tecidos no leito } \\
\text { lesional }\end{array}$} & Granulation $(75-100 \%)$ & 5 & 55.6 & 7 & 77.8 & 0.46 \\
\hline & Devitalised tissue (26-50\%) & 2 & 22.2 & 1 & 11.1 & \\
\hline & Hypergranulation & 2 & 22.2 & 0 & 0.0 & \\
\hline & Hypergranulation/devitalised & 0 & 0.0 & 1 & 11.1 & \\
\hline \multirow{2}{*}{$\begin{array}{l}\text { Quantidade de } \\
\text { exsudato }\end{array}$} & Little & 4 & 44.4 & 0 & 0.0 & 0.15 \\
\hline & Much & 5 & 55.5 & 9 & 100 & \\
\hline Dolor & Present & 7 & 77.8 & 7 & 77.8 & 0.71 \\
\hline Edema & Present & 8 & 88.9 & 8 & 88.9 & 0.76 \\
\hline
\end{tabular}

*Fisher's exact test

\section{Discussion}

In this study, there was a predominance of $77.8 \%$ of adults and male older adults, of individuals in full maturity and who were still in the job market ${ }^{(9-11)}$, in whom the predominant illness was chronic venous insufficiency, considered greater from the third decade of life onward.

Various studies involving patients with the same profile as this sample have evidenced systolic arterial hypertension as the chronic disease which most affects patients with venous ulcers, in whom its percentage can reach $62 \%{ }^{(9-11)}$. Another aggravating factor in the treatment of venous ulcers was the presence of obesity or overweight, as these patients have a tendency to sedentarism and present difficulty in applying the compression therapy(3).

The main anatomical location of the ulcers was the malleolar region. The ulcers can be single or multiple, and can vary in size and location; however, in general, they occur in the distal part of the lower limbs, particularly in the region of the malleolus ${ }^{(11)}$.

The time of evolution of these ulcers counted in months varied from a minimum of 4 (four) months to a maximum of 120 (one hundred and twenty) months.

It is expected that these lesions last for a long time, as chronic lesions occur over a prolonged period and take more time than normal to heal, due to the pre-existing conditions such as pressure, diabetes, poor circulation, poor nutritional status, immunodeficiency or infection. In addition to this, emphasis is also placed on the fact that the time which passes between the appearance of the wound and its total healing, and the possibility of recurrence, are also influenced by the therapy adopted for its treatment ${ }^{(12)}$

The eczema, found around the wound, can be represented by pruritus, erythema and desquamation, affecting the vast majority of patients with venous ulcers, and even increasing the area of the lesion, causing infection when the patients scratch the wound(10-11). The brownish coloration, also known as "ochre dermatitis", is caused by the accumulation of hemosiderin (pigment arising from the death of the blood cells in the subcutaneous tissue)(10-11). All of the distal thirds of the lower limbs affected by the venous wounds presented lipodermatosclerosis, which consists of hardening caused by the chronic edema and fibrosis, which can also be denominated as the inverted champagne bottle deformity ${ }^{(10-11)}$.

The presence of fetid odor was not observed in this study, possibly due to the nursing guidance regarding self-care and to the provision of material, such that the patients could change the secondary dressing at home.

In relation to the reduction of the area of the ulcer in $\mathrm{cm}^{2}$, over the 13 weeks of treatment, it was ascertained that only group B (Unna Boot) presented a significant reduction in the area $\left(\mathrm{cm}^{2}\right)$ throughout all of the evaluations $\left(1^{\text {st }}, 5^{\text {th }}, 9^{\text {th }}, 13^{\text {th }}\right)$. Group A (elastic bandage), on the other hand, only presented a fall in the area of the ulcer in $\mathrm{cm}^{2}(p=0.06)$ after the $5^{\text {th }}$ consultation.

Based on the calculation of the percentage of reduction of the area of the ulcers for each treatment group, it was observed that group B presented a high percentage of reduction of the area of the ulcers $(69.41 \%)$, in comparison with group A (42.32\%).

The tissue found in the wound bed of all the ulcers at the end of the $13^{\text {th }}$ week of treatment with the two compression therapies was that of granulation. This was a positive result, as, at the start of the study, there were ulcers with devitalized tissues and with hypergranulation. Another important data was the presence, at the beginning of treatment, of hypergranulation tissue in the wound bed of two ulcers of the elastic bandage group which, subsequent to treatment with the elastic therapy, presented significant improvement in the quality of the tissue. This result was evidenced in the last evaluation, as the elastic bandage acted as a "physical barrier", 
delaying the process of disorganized stimulation of the granulation tissue found in the ulcers' wound beds.

In relation to the presence of exudate in the ulcers, an increase in the production was observed with the two compression therapies at the beginning of the treatment. In group $B$, the patients undertook a greater number of changes of secondary dressings, twice a day, while group A undertook this once per day. However, at the end of the study, it was evidenced that group $B$ presented greater reduction in the production of exudate in comparison with group A.

The excess of exudate can favor infection, hindering the process of tissue repair, as well as producing odor and discomfort for the patient ${ }^{(12)}$.

Improvement was noted in the grade of the edema in all the patients, after the 13 (thirteen) weeks of treatment. In the first consultation, it was observed that $90 \%$ of the patients presented edema grade $3+/ 4+$, progressing in the last consultation to $+1 / 4+$. The compression therapies - both elastic and inelastic - are the main and most efficient means of controlling edema with venous and lymphatic causes. Rest is also indicated, with the lower limbs being raised to heart level ${ }^{(1,4,6)}$.

In relation to pain, it was noted that in group $B$ there was a greater number of patients who reported pain in using the inelastic compression therapy, in comparison with group $A$. This data corroborates the literature regarding the mechanism of action of the Unna Boot; being an inelastic compression therapy, containing few or no elastometric fibers, this does not mold to the changes in the size of the patient's leg, as well as exercising great pressure on the musculature of the calf of the lower limb in question, during walking and rest ${ }^{(4,6)}$. It is these pressures, acting during rest and walking, which can cause greater discomfort during the use of this therapy ${ }^{(4,6)}$.

The use of compression therapy, during the first weeks of treatment, can cause a slight increase of pain in the patients ${ }^{(4,6)}$.

In relation to the crusts on the margins of the ulcers of the elastic bandage group, the undertaking of mechanical debridement is recommended using a scalpel blade, during the weekly nursing consultations. The appearance of crusts on the margins is more common in dried ulcers, and these must be mechanically debrided using scalpel blades, so that the keratosis may be removed, facilitating the process of healing(2).

The perilesional laceration observed in the Unna Boot group nearly always results from the application of the product directly on the wound and from the abundance of exudate, and reduces with the healing of the wound. Another problem is the loss of the epithelialization tissue during the changing of the dressing, for which reason the recommendation is to abundantly irrigate the dressing with saline solution until it unsticks from the lesion and, at the end of the dressing process, to apply urea cream at $10 \%$ on the edges of the ulcers for hydration.

Urea cream at $10 \%$ was used during all the changings of dressings in all the patients of the study, for hydration of the intact skin around the ulcers. Due to the positive results, the hydration of the skin around the wound is recommended, using hydrating creams based on urea and lanolin, for the maintenance of the skin function and integrity and moisture balance ${ }^{(4,6)}$.

There are complementary measures which facilitate healing and reduce the risk of the appearance of new ulcers, such as resting the lower limbs above the level of the heart for 30 minutes, four times a day, encouragement to take short walks, and maintaining the person's weight within normal limits, as well as avoiding tobacco products and alcoholic drinks ${ }^{(1,4,13)}$.

The patient's adherence to the treatment is important in order to avoid relapses. Various authors have argued that the high number of patients with relapsing ulcers is owed to the fact that the patient did not collaborate in relation to the preventive measures, such as the use of compression therapy following the healing of the ulcers, the lack of post-healing monitoring with angiologists, and not undertaking surgery, among other factors ${ }^{(3-4,6)}$.

\section{Conclusion}

It is concluded that group B (the Unna Boot) was emphasized as the best product for treating venous ulcers, in comparison with the use of the elastic bandage, in a homogenous sample. There was significant reduction, at the level of $5 \%$, in the area $\left(\mathrm{cm}^{2}\right)$ of the ulcers of group $B(p<0.0001)$, throughout the treatment, and there was a tendency in group A for reduction in the area of the ulcer in $\mathrm{cm}^{2}(p=0.06)$ only after the fifth week.

The Unna Boot presented a better result in venous ulcers with areas greater than $10 \mathrm{~cm}^{2}$, and the elastic bandage with Petrolatum ${ }^{\circledR}$ gauze presented a better result in venous ulcers with areas below $10 \mathrm{~cm}^{2}$. in these two treatments, there was an increase in granulation tissue in the wound beds of the ulcers, and reduction in pain and edema. The treatment with the Unna Boot was characterized by significant reduction of the exudate. 
It is recommended that patients using the Unna Boot should change the secondary dressing on a daily basis so as to prevent odor, and that they should use urea cream at $10 \%$ on the wound margins. The patients using the elastic bandage should remove the bandage before sleeping and reapply it in the morning.

The limitation of the study was the difficulty in including patients who were willing to adhere to the treatment in the long-term, and the financial cost of the study.

\section{References}

1. Maffei FHA. Insuficiência venosa crônica: conceito, prevalência etiopatogênia e fisiopatologia. In: Maffei FHA, Lastória S, Yoshida WB, Rollo HA, Giannini M, Moura R. Doenças vasculares periféricas. 4 ed. Rio de janeiro (RJ): Guanabara Koogan; 2008 v. 2. p. 1796-814.

2. Borges EL, Caliri MHL, Haas VJ. Systematic review of topic treatment for venous ulcers. Rev. Latino-Am. Enfermagem. 2007;15(6):1163-70.

3. Fradique C, Pupo A, Quaresma APR, Fernandes M, Gualdino $S$, Almeida $H$, et al. Úlcera flebostática estudo prospectivo de 202 doentes. Acta Med Port. [Internet]. 2011 [acesso 13 dez 2014]; 24(1):71-80. Disponível em: http://www.actamedicaportuguesa.com/revista/ index.php/amp/article/view/341

4. Abreu AM, Oliveira BRB.Uso da atadura elástica como terapia compressiva em úlcera venosa: Relato de experiência. Rev Enferm Profissional [Internet]. 2014 [acesso 13 dez 2014] jul/dez,1(2):489:499. Disponível em: http://www.seer.unirio.br/index.php/ enfermagemprofissional/article/view/3721

5. O'Meara S, Cullum N, Nelson EA, Dumville JC. Compression for venous leg ulcers. Cochrane Database of Systematic Reviews 2012, Issue 11. Art. No.: CD000265. DOI: 10.1002/14651858.CD000265. pub3 Disponível em: http://onlinelibrary.wiley.com/ doi/10.1002/14651858.CD000265.pub3/abstract

6. Abreu AM, Oliveira BRB, Manarte JJ. Treatment of venous ulcers with an unna boot: a case study. Online Braz J Nurs. [Internet]. 2013 [acesso 13 jul 2014]; 12 (1): 198-208. Disponível em: http://www.objnursing. uff.br/index.php/nursing/article/viewFile/3845/pdf_1

7. Harris CL, Bates-Jensen B, Parslow N, Raizman R, Singh $M$, Ketchen R. The Bates-Jensen Wound Assessment Toll (BWAT) (C) Pictorial Guide validadtion project. J Wound Ostomy Continence Nurs. 2010;37(3):253-9.

8. Sousa FF, Pereira LV, Cardoso R, Hortense P. Multidimensional pain evaluation scale. Rev. Latino-Am. Enfermagem. 2010;18 (1):3-10.
9. Sant'ana SMSC, Bachion MM, Santos QR, Nunes CAB, Malaquias SG, Oliveira BGRB. Venous ulcers: clinical characterization and treatment in users treated in outpatient facilities. Rev Bras Enferm. 2012;65(4):637-44. 10. Macedo EAB, Oliveira AKA, Melo GSM, Nobrega WG, Costa IKF, Dantas DV, et al. Characterization sociodemographic of patients with venous ulcers treated at a university hospital. Rev Enferm UFPE. [Internet]. 2010 [acesso 30 jan 2012]; 4 (esp):1919-63. Disponível em: http://www.revista.ufpe.br/revistaenfermagem/ index.php/revista/article/viewArticle/ 1475

11. Oliveira BGRB, Nogueira GA, Carvalho MR, Abreu AM. Caracterização dos pacientes com úlcera venosa acompanhados no Ambulatório de Reparo de Feridas. Rev Eletrônica Enferm. [Internet]. 2011 [acesso 13 jul 2014]; 14(1):156-63. Disponível em: http://www. revistas.ufg.br/index.php/fen/article/view/10322

12. Brett DW. Impact on Exudate Management, Maintenance of a Moist Wound Environment, and Prevention of Infection. J Wound Ostomy Continence Nurs. 2006;33(6S):S9-S14.

13. McDaniel JC, Browning KK. Smoking, Chronic Wound Healing, and Implications for Evidence-Based Practice. J Wound Ostomy Continence Nurs. 2014;41(5):415-23. 